DOI: 10.35784/IAPGOS.242

\title{
SYNTHESIS OF A TRACKING CONTROL SYSTEM OVER THE FLOTATION PROCESS BASED ON LQR-ALGORITHM
}

\author{
Shamil Koshimbaey ${ }^{1}$, Zhanar Lukmanova ${ }^{1}$, Andrzej Smolarz ${ }^{2}$, Shynggyskhan Auyelbek ${ }^{1}$ \\ ${ }^{1}$ Kazakh National Research Technical University named after K.I.Satpayev, Institute of Information and Telecommunication Technologies, Almaty, Kazakhstan, \\ ${ }^{2}$ Lublin University of Technology, Institute of Electronics and Information Technology, Lublin, Poland
}

Abstract. The studies are devoted to the synthesis of the tracking control system of the flotation process based on the LQR-algorithm. The algorithm of finding the parameters of the optimal regulator is given. The results of modelling of the system with the regulator are obtained, and also the comparative analysis of the results of modelling of the system with and without the regulator is shown, which is performed with the help of Matlab software package and the Simulink toolkit.

Keywords: flotation process, optimal regulator, synthesis of the tracking system, LQR-algorithm, Matlab

\section{SYNTEZA NADĄŻNEGO SYSTEMU STEROWANIA PROCESEM FLOTACJI W OPARCIU O ALGORYTM LQR}

Streszczenie. Badania poświęcone sq syntezie nadążnego systemu sterowania procesem flotacji w oparciu o algorytm LQR. Podano algorytm wyszukiwania parametrów regulatora optymalnego. Uzyskano wyniki modelowania układu z regulatorem, a także przedstawiono analizę porównawczQ wyników modelowania układu z regulatorem i bez regulatora, zrealizowana za pomoca pakietu oprogramowania Matlab i biblioteki Simulink.

Slowa kluczowe: proces flotacji, regulator optymalny, synteza systemu nadążnego, algorytm LQR, Matlab

\section{Introduction}

For a long period of time, the flotation process retains a dominant role in the processing of minerals, while the scale of operations still has the tendency for an increase [5]. Foam flotation is one of the most commonly used methods for the separation of ore in the processing industry. Despite numerous researches and developments in this area, as well as potential large economic benefits that can be obtained by optimization of the enrichment process, there are still questions how to select key operational variables at which the flotation process would be more effective [3]. A flotation unit control system usually consists of ordinary single-loop controllers. However, the use and maintenance of control systems based on modern control theory has been proven as problematic in an industrial environment [7]. As a result, there were implemented expert control strategies for the logical management of situations [6]. Stable operation of flotation cells depends on the implementation of basic distributed control systems [2].

The lack of accurate measurements, nonlinear dynamics and high interaction between variables are among the main problems associated with stabilization of control. These characteristics reduce the effectiveness of control over conventional PIDregulator with manual setting in order to coordinate control loops. The use of basic distributed control often led to significant variability in the concentrate grade and its restoration, which can be observed in many concentrates around the world [1].

\section{Problem statement}

The main technological parameters in the flotation machine include: the level of pulp from the overflow threshold, the degree of aeration, the density of the pulp, the total height of the foam layer and the foam layer above the overflow threshold. In order to optimize the process of flotation of mineral raw materials, it is necessary to measure continuously and promptly the following process parameters: reagent consumption by dosing points, input and output reagent flow consumption, the pulp level in the cells of flotation machines, the degree of pulp aeration, the height of the foam layer, the specific weight of the foam layer [8]. Therefore, properly tuned and well-functioning regulators are the basis for successful control over the flotation process. The MatLab system with the Simulink extension was used as a working modelling tool.
Problem statement of the optimal regulator synthesis

There is presented a classical model of the control object in the state space:

$$
\left\{\begin{array}{c}
\dot{x}(t)=A x(t)+B u(t) \\
y(t)=C^{T} x(t)
\end{array},\right.
$$

The control law implemented by the P-regulator is described by the formula:

$$
u(t)=-k^{T} x(t)
$$

One of the methods for the synthesis of regulator parameters is based on finding the minimum of the integral quadratic quality criterion:

$$
I(t)=\int_{0}^{\infty}\left(x^{T}(t) Q x(t) d t+u^{T}(t) R u(t)\right) d t \rightarrow \min ,
$$

For the model of the control object in the state space (1), it is necessary to synthesize the P-regulator (2), which minimizes the integral quadratic quality criterion (3).

\section{Algorithm for finding of the optimal controller parameters}

In order to solve this problem, let consider the mathematical model of the Frobenius method:

$$
\begin{gathered}
\left|\begin{array}{c}
\dot{x_{1}} \\
\dot{x_{2}}
\end{array}\right|=\left|\begin{array}{cc}
0 & 1 \\
-0.00002292 & -0.01241821
\end{array}\right| \times\left|\begin{array}{l}
x_{1} \\
x_{2}
\end{array}\right|+ \\
+\left|\begin{array}{cc}
0 \\
0.00015129
\end{array}\right| \times u(t),
\end{gathered}
$$

Where the quality criterion has the following form:

$$
I(t)=\int_{0}^{\infty}\left(\left|\begin{array}{l}
x_{1} \\
x_{2}
\end{array}\right|^{T} \times\left|\begin{array}{ll}
1 & 0 \\
0 & 1
\end{array}\right| \times\left|\begin{array}{l}
x_{1} \\
x_{2}
\end{array}\right|+u^{T}(t) 1 u(t)\right)
$$

In order to implement the optimal regulator, there is used the program listing in MatLab:

> $\mathrm{A}=[0$ 1;-0.00002292 -0.01241821];

$>\mathrm{B}=[0 ; 0.00015129]$;

$>\mathrm{C}=[10]$

$>\mathrm{D}=0$;

$>\mathrm{Q}=$ eye $(2)$;

$>\mathrm{R}=1$;

$>$ sys $=$ ss $(A, B, C, D)$;

$\gg[\mathrm{K}, \mathrm{S}, \mathrm{e}]=\operatorname{lqr}(\mathrm{sys}, \mathrm{Q}, \mathrm{R})$

$\mathrm{K}=$

$0.8599 \quad 52.4772$

$\mathrm{S}=$

$1.0 \mathrm{e}+05 *$

$0.0012 \quad 0.0568$

$0.0568 \quad 3.4687$ 
$\mathrm{e}=$

$-0.0102+0.0070 \mathrm{i}$

$-0.0102-0.0070 \mathrm{i}$

where $\mathrm{K}$ - optimal gain matrix;

$\mathrm{S}$ - solution of the related Ricatti equation;

$\mathrm{e}-\left(\mathrm{A}-\mathrm{Bk}^{\wedge} \mathrm{T}\right)$.

Therefore, the optimal values of the P-regulator parameters during the object control are determined by formulas (4) and (5) and will have the following form:

$$
\begin{gathered}
u(t)=-k^{T} x(t)=-\left|k_{1} \quad k_{2}\right| \times\left|\begin{array}{l}
x_{1} \\
x_{2}
\end{array}\right|= \\
-0.8599 x_{1}(t)-52.4772 x_{2}(t),
\end{gathered}
$$

\section{Obtaining the modelling results of a system with a regulator}

The regulator is described by a model in the state space:

$$
\begin{aligned}
& u(t)=-k^{T} x(t)=-\left|k_{1} \quad k_{2}\right| \times\left|\begin{array}{l}
x_{1} \\
x_{2}
\end{array}\right| \\
& =-0.8599 x_{1}(t)-52.4772 x_{2}(t)
\end{aligned}
$$

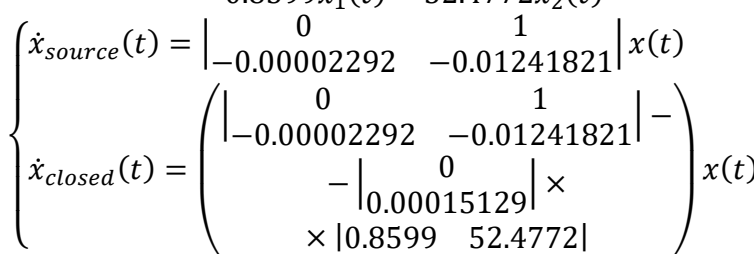

$$
\begin{aligned}
& \left\{\dot{x}_{\text {closed }}=\left|\begin{array}{l}
\dot{x_{1}} \\
\dot{x_{2}}
\end{array}\right|=\right.
\end{aligned}
$$$$
x_{2}
$$

$-0.00002292 x_{1}-0.01241821 x_{2}-0.8599 x_{1}-52.4772 x_{2}$, (9)

The simulation scheme using the Simulink Design library is shown on the Figure 1.

In order to start the system with a regulator in the Simulink software application, you need to: connect the unit to a signal whose value you need to adjust - the permissible limits of the transition process and the steady-state value of the parameters of the controlled signal.

As a result of the simulation, the following values of the regulator parameters were proposed: $\mathrm{k} 1=-0.00002292$; $\mathrm{k} 2=-0.01241821 ; \mathrm{k} 3=-0.8599 ; \mathrm{k} 4=-52.4772$;

A simulation diagram of the comparative analysis without and with a regulator is shown on Figure 3.

Figure 1 shows a diagram of a system with a regulator, the oscilloscope displays a transition process, where the initial conditions of which negatively tend to infinity and does not coincide with the model in the state space. The Figure 4 shows a diagram of a system without a regulator, where the transition process coincides with the model in the state space and is equivalent to it.

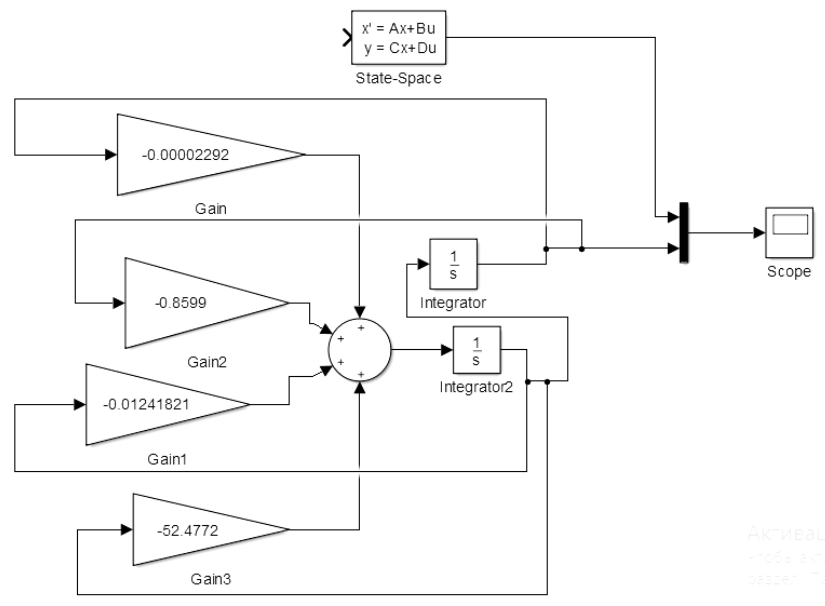

Fig. 1. Model of a system with a regulator in Simulink

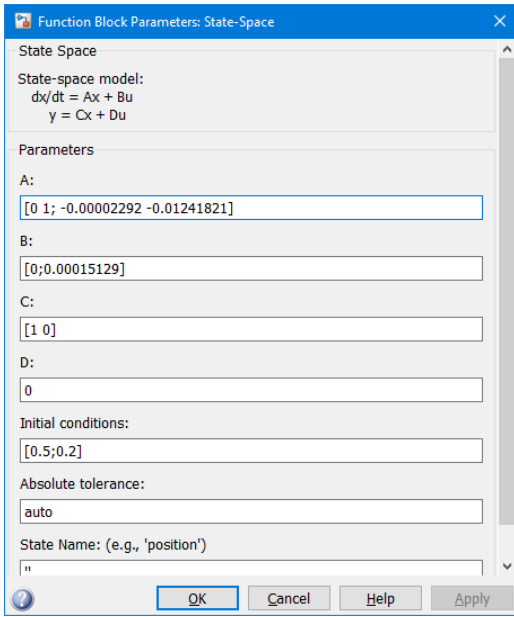

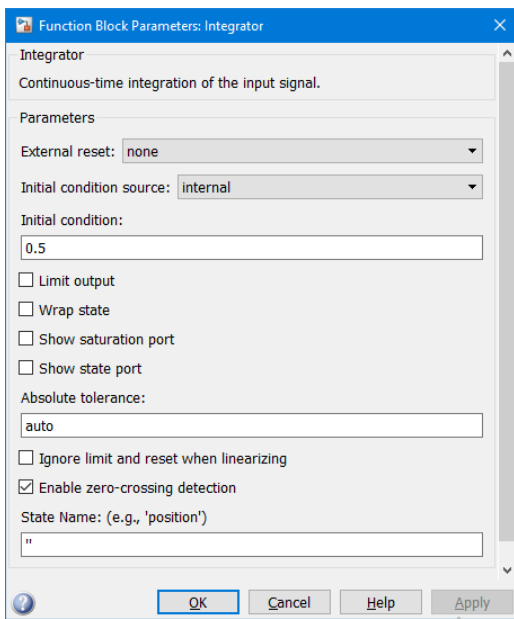

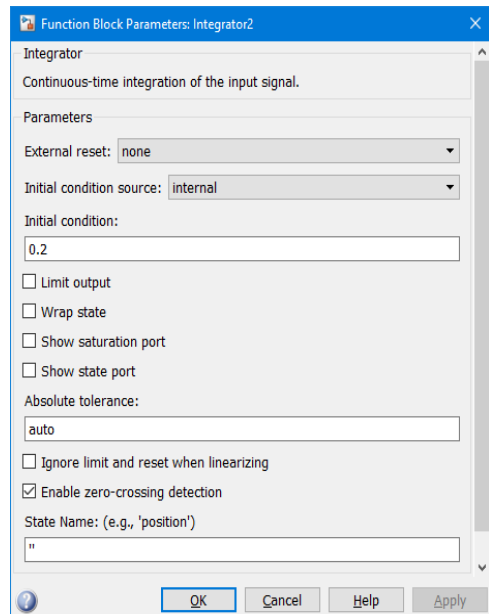

Fig. 2. Initial conditions of a regulator parameter

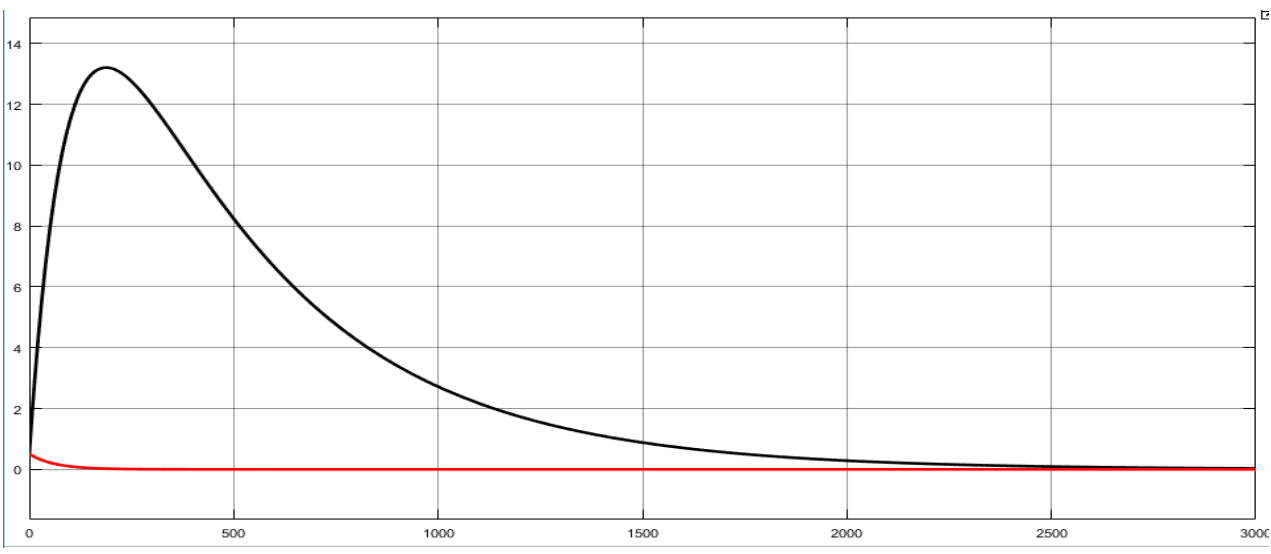

Fig. 3. System parameter process with and without a regulator 


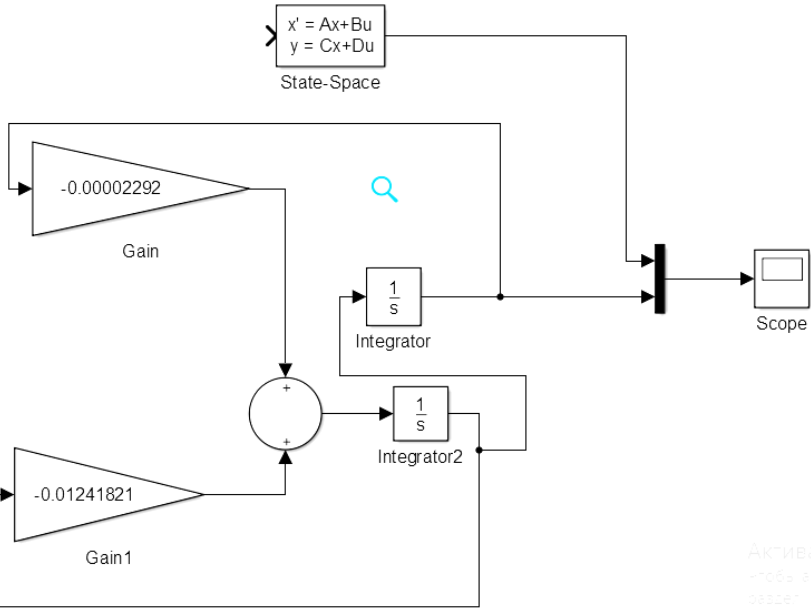

Fig. 4. Diagram of a system without a regulator in Simulink

\section{Synthesis of the servo system}

The method of analytical construction of regulators according to the criterion of generalized operation (AKOR), developed by A.A. Krasovsky, allows the synthesis of regulators for objects described by systems of ordinary nonlinear differential equations of higher order, which compares favourably with many other methods for the synthesis of optimal regulators [4]. In this case, the mathematical model of the control object in the most general case has the form:

$$
\left\{\begin{array}{c}
\dot{x}(t)=A x(t)+B\left(-k^{T} x(t)\right)+B * N b a r * r(t), \\
y(t)=C^{T} x(t)
\end{array},\right.
$$

In order to obtain the simulation result of the servo system, it is necessary to create a file-function:

function[Nbar]=rscale $(\mathrm{a}, \mathrm{b}, \mathrm{c}, \mathrm{d}, \mathrm{k})$

error(nargchk(2,5,nargin));

nargin $1=$ nargin;

if $($ nargin $1==2)$,

$[\mathrm{A}, \mathrm{B}, \mathrm{C}, \mathrm{D}]=\operatorname{ssdata}(\mathrm{a})$;

$\mathrm{K}=\mathrm{b}$;

elseif (nargin $1==5$ ),

$\mathrm{A}=\mathrm{a} ; \mathrm{B}=\mathrm{b} ; \mathrm{C}=\mathrm{c} ; \mathrm{D}=\mathrm{d} ; \mathrm{K}=\mathrm{k}$;

else error('Input must be of the form (sys,K) or $(\mathrm{A}, \mathrm{B}, \mathrm{C}, \mathrm{D}, \mathrm{K})$ ')

end;

$\%$ compute Nbar

$\mathrm{s}=\operatorname{size}(\mathrm{A}, 1)$

$\mathrm{Z}=[\operatorname{zeros}([1, \mathrm{~s}]) 1]$;

$\mathrm{N}=\operatorname{inv}([\mathrm{A}, \mathrm{B} ; \mathrm{C}, \mathrm{D}]) * \mathrm{Z}^{\prime}$

$\mathrm{Nx}=\mathrm{N}(1: \mathrm{s})$
$\mathrm{Nu}=\mathrm{N}(1+\mathrm{s})$

$\mathrm{Nbar}=\mathrm{Nu}+\mathrm{K} * \mathrm{Nx}$;

Let save the program as rscale.m. After this process, we get the number Nbar in MatLab:

> Nbar=rscale(sys,K)

Nbar $=$

1.0114

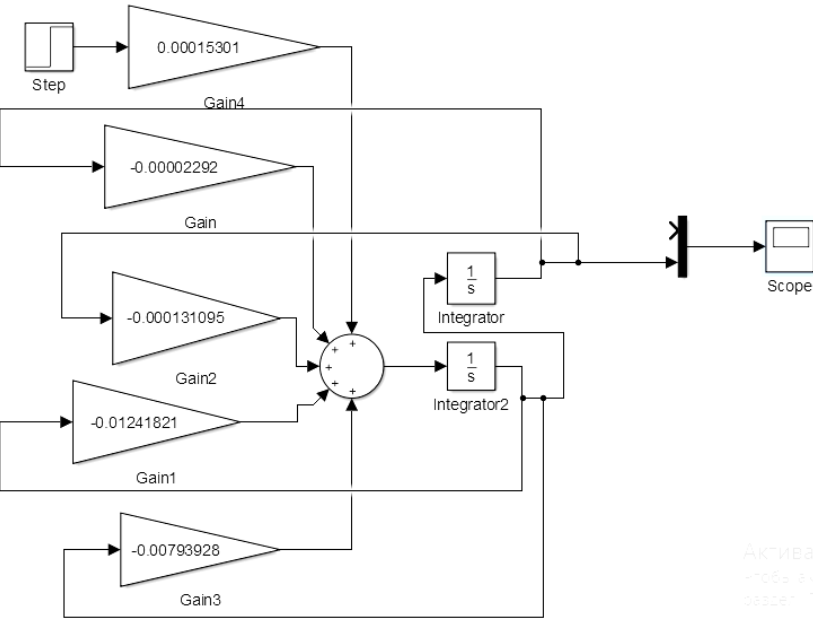

Fig. 5. Servo system model in Simulink

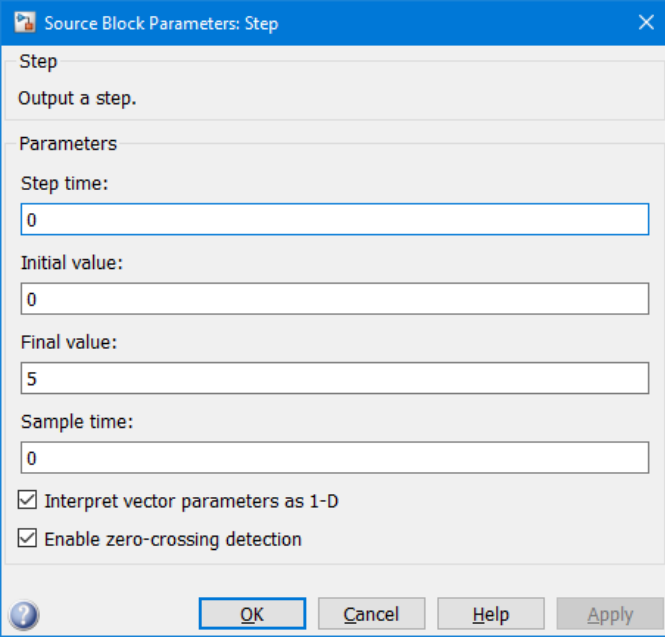

Fig. 6. Input signal parameters

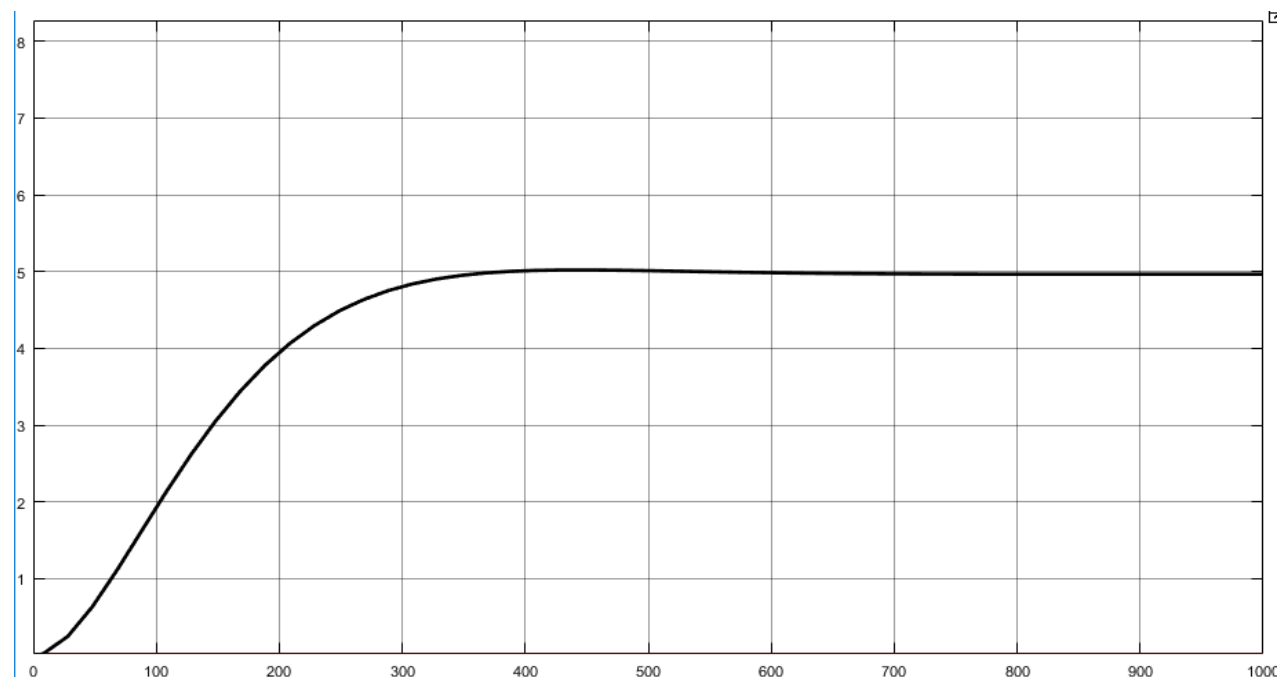

Fig. 7. Modeling result 
Therefore, the optimal parameters of the regulator are solved. There are presented the system simulation algorithms with and without a regulator. Was developed a synthesis of a servo control system over the flotation process based on the LQR - algorithm. Solving the problem of choosing the optimal regulator parameters, it is necessary to check whether the system under study is controlled and observable. If not, then the synthesis is impossible. Obviously, in order to determine these properties, the A, B, C equations matrices of variable states are used that characterize the input and output parameters of the mode of the system under study.

\section{Ph.D. Shamil Koshimbayev}

e-mail: shamil.koshimbaiev@mail.ru

University studies: Kazakh Polytechnic Institute named after V.I. Lenin, Automation of metallurgical production.

Scientific interest: automation, metallurgy, SCADA systems, dynamic modelling.

Experience: 48 years.

\section{ORCID ID: 0000-0002-3718-6860}

\section{M.Sc. Zhanar Lukmanova}

e-mail: zhanar.lukmanova@gmail.com

Current position, grades: doctoral student at the Kazakh National Research Technical University named after K.I. Satpayev.

University studies: master of technical sciences.

Scientific interest: automation, flotation, intellectua systems, SCADA - systems, simulation modelling.
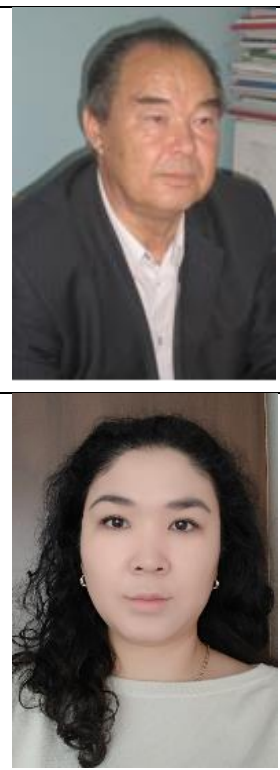

ORCID ID: 0000-0001-5938-8220

\section{References}

[1] Batterham R.J., Robinson D.J.: Will In-Place Recovery Ever Replace the Need for Flotation? Mining. Metallurgy \& Exploration 2019.

[2] Bergh L.G., Yianatos J.B.: Flotation column automation: state of the art. Control Engineering Practice 11/2003.

[3] Bergh L., Yianatos J., Bravo G.: On-line monitoring of a pilot flotation rougher circuit by using PCA models. IFAC PapersOnLine 2018, 335-340.

[4] Dmitrienko V.D., Noskov V.I., Mezentsev N.V.: Synthesis of regulators by the ACOR method by A.A. Krasovsky with nonlinear input controls and random disturbances. Bulletin of the National Technical University Kharkov Polytechnic Institute 13/2009, 53-60.

[5] Fuerstenau M.C., Jameson G.J., Yoon R-H.: Froth flotation: a century of innovation. SME 2007

[6] Jamsa S.-L., Herbst J.A.: A simulation study of expert control system for flotation. Software for Computer Control, New York 1988

[7] Jamsa-Jounela S.-L., Dietrich M., Halmevaara K., Tiili O.: Control of pulp levels in flotation cells. Control Engineering Practice 11/2003, 73-81.

[8] Lavrienko A.A., Fedin G.V.: Instruments for control over the main technological parameters in the flotation process of mineral raw materials. MIAB 1/2012.

\section{D.Sc. Andrzej Smolarz}

e-mail: a.smolarz@pollub.pl

Associate professor at Lublin University of technology, Institute of Electronics and Information Technology. Deputy Head of Institute for Scientific Affairs. Main fields of interest: modelling, neural networks, artificial intelligence, combustion diagnostics and control, new communication technologies.

\section{ORCID ID: 0000-0002-6473-9627}

\section{Student Shyngyskhan Auyelbek}

e-mail: shyngys.assylbek@mail.ru

2016-2017 (practice) Kazakhstan-French scientifically-educational centre Schneider Electric. Laureate of grant from a company "Chevron" technical specialities, 2015. A possessor of the honoured rank is a "student of year - 2017", for the highest indexes in handing over of the External estimation of educational achievements in a university, 2017. Winner in the open cup of city Almaty on Grappling and Pankration 2015. Possessor 3 digits on a chess piece.

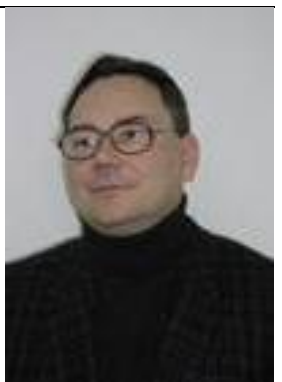

ORCID ID: 0000-0002-4832-6996

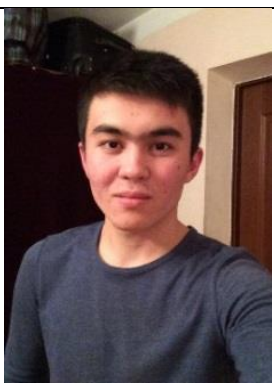

otrzymano/received: 30.05 .2019

przyjęto do druku/accepted: 15.06 .2019 